IZA DP No. 5762

Quality and Quantity in Primary Care Mixed Payment Models: Evidence from Family Health Organizations in Ontario

Jasmin Kantarevic

Boris Kralj

June 2011 


\title{
Quality and Quantity in Primary Care Mixed Payment Models: Evidence from Family Health Organizations in Ontario
}

\author{
Jasmin Kantarevic \\ Ontario Medical Association \\ and IZA \\ Boris Kralj \\ Ontario Medical Association
}

\section{Discussion Paper No. 5762 \\ June 2011}

\author{
IZA \\ P.O. Box 7240 \\ 53072 Bonn \\ Germany \\ Phone: +49-228-3894-0 \\ Fax: +49-228-3894-180 \\ E-mail: iza@iza.org
}

Any opinions expressed here are those of the author(s) and not those of IZA. Research published in this series may include views on policy, but the institute itself takes no institutional policy positions.

The Institute for the Study of Labor (IZA) in Bonn is a local and virtual international research center and a place of communication between science, politics and business. IZA is an independent nonprofit organization supported by Deutsche Post Foundation. The center is associated with the University of Bonn and offers a stimulating research environment through its international network, workshops and conferences, data service, project support, research visits and doctoral program. IZA engages in (i) original and internationally competitive research in all fields of labor economics, (ii) development of policy concepts, and (iii) dissemination of research results and concepts to the interested public.

IZA Discussion Papers often represent preliminary work and are circulated to encourage discussion. Citation of such a paper should account for its provisional character. A revised version may be available directly from the author. 


\section{ABSTRACT}

\section{Quality and Quantity in Primary Care Mixed Payment Models: Evidence from Family Health Organizations in Ontario*}

We study the impact of a mixed capitation model known as the Family Health Organization (FHO) on selected quality and quantity outcomes relative to an enhanced fee-for-service model known as the Family Health Group (FHG) among primary care physicians in Ontario, Canada. Using a panel of administrative data that covers one year before and two years after the FHO model was introduced in 2007, we find that physicians in the FHO model provide about 6 percent fewer services and visits per day, but are between 8 and 15 percent more likely to achieve preventive care bonuses for senior flu shots, toddler immunizations, pap smears, and mammograms compared to physicians in the FHG model. These results are largely consistent with the hypothesis that the mixed payment model may reduce quantity and improve quality of health care relative to the fee-for-service model. We also find that the $\mathrm{FHO}$ physicians have lower referral rates and enroll patients of similar complexity compared to the FHG physicians.

\section{NON-TECHNICAL SUMMARY}

We study the performance of a blended capitation primary care model relative to an enhanced fee-for-service model in Ontario, Canada. We find that physicians in the blended capitation model provide fewer services and visits but work a similar number of days and have a similar number of enrolled patients. On the other hand, we find that physicians in the blended capitation model are more likely to reach preventive care targets for flu shots, pap smears, mammograms, immunization, and colorectal screening. These results indicate that the blended capitation model may reduce quantity and improve quality of health care relative to the fee-for-service model.

JEL Classification: I10, I12, I18

Keywords: physician remuneration, primary care, Family Health Organizations, Family Health Groups, Ontario, Canada

Corresponding author:

Jasmin Kantarevic

Ontario Medical Association

525 University Avenue

Toronto, ON M5G 2K7

Canada

E-mail: jasmin_kantarevic@oma.org

\footnotetext{
* The views expressed in this paper are strictly those of the authors. No official endorsement by the Ontario Medical Association is intended or should be inferred.
} 


\section{Introduction}

The traditional fee-for-service (FFS) model, in which physicians receive a fee for each service they provide, has been and still remains the predominant payment model in many developed countries, including Canada and the United States. This model has been criticized for long time because it may encourage over-provision of health care ${ }^{1}$. Furthermore, the model has been criticized because it typically lacks incentives to provide valuable but hard to observe quality of care $^{2}$. These two criticisms are particularly relevant in the current era of growing health expenditures and concerns about value for money.

As a promising alternative, the recent literature has advocated a mixed payment model in which physicians receive a reduced fee for each service they provide and a fixed payment for each enrolled patient. Theoretically, this model may be designed to induce the socially optimal levels of both quantity and quality of health care ${ }^{3}$. Empirically, however, it is still not well understood how this model performs relative to the FFS model, especially among primary care physicians $^{4}$.

In this paper, we provide new evidence on this question by studying a mixed payment model known as the Family Health Organization (FHO) that was introduced in Ontario, Canada in $2007^{5}$. We compare the impact of this model on selected quantity and quality outcomes relative to an enhanced fee-for-service model known as the Family Health Group (FHG). The comparison between the two models is particularly revealing because the majority of physicians who joined the FHO model were previously in the FHG model. The comparison is also

\footnotetext{
${ }^{1}$ See for example Evans (1974).

${ }^{2}$ See for example McGuire (2000).

${ }^{3}$ See for example Léger (2008), McGuire (2008), and Zweifel et al. (2009).

${ }^{4}$ For evidence on specialists, see for example Dumont et al. (2008) and Fortin et al. (2010).

5 The FHO contract was finalized with the effective date of November 2006, but its implementation was delayed until the summer of 2007.
} 
important from a policy perspective because the FHO and the FHG are currently two most prevalent primary care models in Ontario, comprising about 60 percent of all family physicians.

Our analysis is based on a panel of rich administrative data that follows a cohort of FHG physicians from 2006 to 2009, including over one year before and over two years after the FHO model was introduced. Over this sample period, about one third of FHG physicians switched to the new FHO model. Because this transition was voluntary, we use a two-step approach to address the concern that physicians who joined the FHO model were a selected, non-random sample of FHG physicians. In the first step, we use the propensity score method to match treatment and control physicians based on their observed characteristics prior to the introduction of the FHO model. In the second step, we employ a difference-in-difference model with fixed physician effects and physician-specific trends to control for unobserved, time-invariant physician heterogeneity and to account for differential trends in outcomes between treatment and control physicians.

We find that physicians in the FHO model provide about 6 percent fewer services and visits per day (about 2 fewer services or visits per day), but work the same number of days per year and enroll the same number of patients compared to physicians in the FHG model. On the other hand, physicians in the FHO model are between 8 and 15 percent more likely to achieve preventive care bonuses for senior flu shots, toddler immunizations, pap smears, and mammograms than physicians in the FHG model. These results are largely consistent with the hypothesis that the mixed payment model may reduce quantity and improve quality of health care relative to the FFS model. To the extent that the FFS model delivers too much quantity and too little quality, as the critics argue, these results suggest that the mixed capitation model may be welfare enhancing relative to the FFS model. 
We also study the performance of the FHO model with respect to two common concerns about capitation models: patient selection or 'cream-skimming' and excessive referrals ${ }^{6}$. We find that the FHO physicians have about 4 percent fewer referrals per rostered patient than the comparable FHG physicians. We also find no significant difference in the patient complexity between the two models, as measured by age-sex specific multipliers used to risk-adjust capitation payments in the FHO model. These results suggest that joining the mixed capitation model have no adverse consequences on patient selection or referrals compared to the FFS model.

This analysis complements our earlier study of the transition of FFS physicians to the FHG model (Kantarevic et al., 2010). That transition, following the introduction of the FHG model in 2003, involved incremental changes to how physicians are paid, but the main method of payment remained the FFS system. In this paper, we study a more radical payment reform in which physicians transitioned from an enhanced FFS model (the FHG) to a mixed capitation model (the FHO). As Figure 1 shows, these two transitions from the traditional FFS model - to the enhanced FFS model and to the mixed capitation model - represent two main stages in the Ontario primary care reform in the last ten years.

Our study is also of direct policy relevance to other jurisdictions. The first relevance is to the concept of Patient-Centered Medical Homes (PCMH) that has recently become quite popular in the United States. The PMCHs are envisioned as multidisciplinary teams based on principles of coordinated and integrated care, quality and safety, enhanced access, and payment system that rewards value ${ }^{7}$. In Ontario, the principles of the PCMH are closely embedded in the interdisciplinary Family Health Teams in which most participating physicians are signatories to the

\footnotetext{
${ }^{6}$ See for example Léger (2008).

${ }^{7}$ For a brief review of the PCMH, see for example a report by Robert Graham Center (2007).
} 
FHO model ${ }^{8}$. The second policy relevance is to the Quality and Outcomes Framework that was introduced in the U.K. in $2004^{9}$. This Framework included 146 indicators of quality across seven areas of physician practice. About half of available quality points are for clinical indicators that are typically awarded if a minimum percent of eligible patients receives the targeted type of care. This payment structure for clinical quality is quite similar to the preventive care bonuses in Ontario that we study in this paper.

The rest of the paper is organized as follows. The next section provides a detailed comparison between the FHO and FHG models. Section 3 then briefly reviews the literature on the impact of mixed payment model on the quantity and quality of health care. Section 4 describes our data and empirical strategy. Section 5 discusses the FHO impact on quantity and quality outcomes, while Section 6 discusses the impact on patient selection and referrals. Section 7 concludes.

\section{Institutional Background}

To appreciate changes involved in the transition from the FHG model to the FHO model, we compare the two models along three main dimensions of physician practice: organization, base compensation, and performance-based incentives (see Table 1).

The organization of the two models is quite similar. Both models are group models with at least three physicians, with identical after-hour obligations ${ }^{10}$, and similar patient enrolment requirements. In the FHO model, the enrolment is stipulated by the contract; in the FHG model,

\footnotetext{
${ }^{8}$ See for example Rosser et al. (2010).

${ }^{9}$ For a brief overview, see for example Smith and York (2004).

${ }^{10}$ For example, the minimum requirement for the group of three physicians is to provide a three-hour block of care per week per physician during the after-hour period (evenings on weekdays or any time on weekends and holidays).
} 
the enrolment is optional but strongly encouraged because most financial incentives apply to enrolled patients only.

The main difference between the two models is in their base compensation. In the FHO model, physicians receive an age-sex adjusted capitation rate ${ }^{11}$ for providing a set of core services to their enrolled patients ${ }^{12}$. In addition, the FHO physicians receive 10 percent of the FFS value of core services provided to their enrolled patients and 100 percent of the FFS value of core services provided to the non-enrolled patients (up to a hard cap ${ }^{13}$ ). For the non-core services, the physicians receive the full FFS value with no hard cap. Specifically, the base compensation in the FHO model can be represented as:

$$
I_{\mathrm{FHO}}=R m+0.1 p_{1} q_{1} m+p_{2} q_{2}(m+n)+\min \left\{p_{1} q_{1} n, z\right\}
$$

where $R$ is the capitation rate ${ }^{14}, m$ is the number of enrolled patients, $p_{1}$ and $q_{1}$ are the price and quantity of core services, $p_{2}$ and $q_{2}$ are the price and quantity of non-core services, $n$ is the number of non-enrolled patients, and $z$ is the hard cap on core services provided to non-enrolled patients.

In contrast, physicians in the FHG model receive no capitation payment but they receive the full FFS value for all services provided to both enrolled and non-enrolled patients. In addition, the FHG physicians receive a 10 percent premium for a set of comprehensive care

\footnotetext{
${ }^{11}$ The age-sex specific modifier includes 19 five-year age categories for each sex. The modifier ranges from 0.44 for males 10-14 years of age to 2.71 for females over 90 years of age, with the provincial average standardized to 1 .

${ }^{12}$ The FHO core basket includes over 100 comprehensive care services. The complete list of codes is available upon request.

${ }^{13}$ In 2008, the value of the hard cap was $\mathrm{C} \$ 48,500$.

${ }^{14}$ In the FHO contract, physicians receive a net capitation rate plus an access bonus of up to 18.59 percent if their enrolled patients receive the core services exclusively from the physicians in the group. The average annual value of gross capitation rate (the net rate plus the full value of access bonus) is equal in value to about five office visits.
} 
services provided to their enrolled patients ${ }^{15}$. Specifically, the base compensation in the FHG model can be represented as:

$$
I_{\mathrm{FHG}}=1.1 p_{1} q_{1} m+p_{1} q_{1} n+p_{2} q_{2}(m+n)
$$

where $q_{1}$ now represents services eligible for the 10 percent comprehensive care premium and $q_{2}$ represents other services.

Despite these differences, the base compensation contains two elements common to both models: a 20 percent premium for selected services provided to enrolled patients during afterhours ${ }^{16}$ and the Comprehensive Care Capitation (CCC) fee for each enrolled patient ${ }^{17}$. The CCC fee is paid for commitment to provide comprehensive care services to enrolled patients and not for the actual provision of services. For this reason, the CCC fee is better interpreted as a transfer payment designed to meet the participation constraint of FFS physicians interested in joining a primary care model rather than the actual capitation payment.

Lastly, physicians in both models are eligible for a common set of performance-based incentives. These include preventive care bonuses, chronic disease management fees, and incentives to enroll patients with no regular family doctor. The preventive care bonuses are paid if the specific percentage of enrolled and eligible patients receives a defined type of care (pap smears, mammograms, flu shots, immunizations, and colorectal screening). The chronic disease management fees are paid annually for providing required elements of service and currently apply to patients with diabetes and congestive heart failure. The incentives to attach patients are paid as a one-time payment at the time of attachment, and differentiate between regular patients,

\footnotetext{
${ }^{15}$ Services eligible for the 10 percent comprehensive care premium include assessments in office, emergency department and patient home; pap smear, immunization, flu shot, and annual health exam; primary mental health, HIV, and palliative care; and diabetic assessment. Most of these services are also included in the FHO core basket.

${ }^{16}$ The main services eligible for the 20 percent after-hour premium include a subset of services eligible for the 10 percent comprehensive care premium.

${ }^{17}$ The average annual value of this fee is slightly below the value of one office visit.
} 
patients discharged from hospital, complex or vulnerable patients, and unattached mothers with newborns.

In addition to these common incentives, there also exists a set of special payments that until 2009 applied to the FHO physicians only. These bonuses were paid for providing services deemed to be in short supply (obstetrical deliveries, hospital services, prenatal care, home visits $)^{18}$. In 2009, the level of bonuses and the type of targeted services significantly changed and the eligibility was extended to all family physicians.

In summary, then, the FHG and FHO physicians share similar organizational structure and are eligible for a similar set of performance-based incentives. The main difference between the two models is in their base compensation. This difference resembles the stylized distinction between the FFS model, in which physicians are paid a full fee for each service they provide but receive no capitation payment, and the mixed capitation model, in which physicians receive a capitation payment and also a partial fee for each service they provide.

\section{Expected Impact of Mixed Capitation Model}

In this section, we briefly review theoretical and empirical literature that examines the relative merits of the FFS model and the mixed capitation model in achieving two important goals of primary care reforms: reducing costs and improving quality.

We start with the fee-for-service model. It is usually argued that physicians in this model tend to over-provide care because their income is directly related to the number of services provided (e.g. McGuire, 2000). This argument is further strengthened by the fact that physicians are generally better informed than patients and insurers about the appropriate level of care (e.g.

\footnotetext{
${ }^{18}$ There were also two special payments, for palliative care and serious mental illness, for which both the FHG and FHO physicians were eligible during the sample period.
} 
Evans, 1974). Even if this information was symmetric, physicians may exploit their quantitysetting power to induce patients to consume more than the efficient level of care (e.g. McGuire, 2000). On the other hand, the argument about the over-provision of care in the FFS model is weakened if physicians are sufficiently altruistic or if the role of medical ethics is sufficiently strong (e.g. Evans, 1974). The empirical evidence on the impact of the FFS model on the provision of care is in general mixed (see McGuire, 2000 for a review), and where the evidence supports the over-provision argument, the estimated impact is relatively small (e.g. Gruber and Owings, 1996; Yip, 1998).

Perhaps a more important concern with the FFS model is that it lacks incentives to provide the efficient level of quality. This concern arises because the quality is usually hard to observe and measure and therefore it is typically not rewarded in the FFS model. The concern remains even when the quality can be observed but imperfectly. In such a multitasking environment, in which the compensation can be based on both the quantity and quality of care, the optimal contract usually deviates from the high-powered FFS model (e.g. Holmstrom and Milgrom, 1991; Chakley and Malcomson, 1998; Eggleston, 2005). Again, the argument about the under-provision of quality in the FFS model is weakened if physicians are altruistic or if the role of medical ethics is strong.

Consider next the mixed capitation model. By reducing the fee below the marginal cost of providing the service, it is possible to induce physicians to reduce the quantity of care, perhaps even to the efficient level (e.g. McGuire, 2008; Léger, 2008). However, eliminating the fee for service completely, as in a pure capitation model, may not be optimal when physicians are risk averse or when they have superior information about the case-mix of patients (Zweifel et al., 2009). 
The mixed payment method can also help improve the quality of care. This improvement can arise if the patients choose their physicians based on the observed but unverifiable quality of care (McGuire, 2000). Because physicians' incomes depend on the capitation payment they receive for each patient, they have incentives to provide the efficient level of quality even though the quality is not directly rewarded. However, the impact of physician competition for patients on the quality of care may depend on the costs of switching physicians and on the extent to which the patient can infer quality from observed health outcomes (Allard et al., 2006). The mixed payment system can also provide the appropriate incentives for the quality of care when the patient demand for treatment depends on the observed but unverifiable quality (Ma and McGuire, 1997). Specifically, when the quality and treatment are substitutes, the optimal contract includes a fee for each service that is below the marginal cost of providing the service, as in the stylized mixed payment model.

The empirical evidence on the impact of the mixed payment model is surprisingly scarce. In a recent study by Dumont et al. (2008), the authors study the introduction of a mixed payment system (a per diem rate plus a pro-rated fee for service) for specialists in Quebec in 1999. Relative to the FFS model, physicians who participated in the mixed payment model reduced billable services by about 6 percent, but increased time per service by about 4 percent and also increased their time on administration and teaching by about 8 percent. Fortin et al. (2010) study the same reform and find similar results, even though their study is limited to pediatricians. The main concern with these studies, as the authors acknowledge, is that time per service may not be a perfect measure of quality because it does not distinguish between time spent with patients and time spent in other activities, nor does it provide information on its effect on patient outcomes. In addition, both studies focus on specialists rather than primary care physicians. 
This brief review of literature suggests that physicians in the mixed capitation model may provide lower quantity but higher quality of care than physicians in the FFS model. Given the concern that the FFS physicians may provide inefficiently high quantity of care and inefficiently low quality of care, the mixed capitation model may therefore be welfare enhancing. However, this conclusion need not hold in general because physician behavior may also be influenced by other factors such as altruism, medical ethics, malpractice suits and monitoring. Therefore, the impact of the mixed capitation system on the quantity and quality of care ultimately remains an empirical question.

\section{Data and Empirical Strategy}

\subsection{Data}

The data comes from several administrative sources maintained by the Ontario Ministry of Health and Long-Term Care ${ }^{19}$. These sources can be linked together using encrypted physician and patient numbers to construct a rich and comprehensive database that includes almost all family physicians and insured patients in Ontario $^{20}$. From this database, we select the sample of all physicians affiliated with a FHG model as of April 1, 2006 (4,489 physicians, or about 40 percent of all family physicians in Ontario). This cohort of physicians is then followed for four fiscal years through March 31, 2010. This sample period includes over one year before and over two years after the FHO model was introduced in 2007.

Over the sample period, some physicians remained in the FHG model, while others switched to other models, predominantly the FHO. We define the treatment indicator as a continuous variable between 0 and 1 that measures the proportion of year during which the

\footnotetext{
${ }^{19}$ The data sources are described in Appendix Table 1.

${ }^{20}$ Physicians without any FFS billings or primary care payments, such as salaried physicians, are not included in our database. However, this group represents less than 1 percent of family physicians in Ontario.
} 
physician was affiliated with the FHO model rather than the FHG model ${ }^{21}$. Using this definition, the initial cohort consists of 4,133 physicians in 2006, all of whom are in the FHG model (see Figure 2). By 2009, about two thirds of this cohort remained in the FHG model $(2,474$ physicians), while about one third was now in the FHO model (1,358 physicians $)^{22}$.

We compare the treatment and control physicians with respect to selected measures of quantity and quality of care. The quantity measures include the number of services per day, the number of visits per day, the number of annual days of work, and the roster size (as of the last day of each fiscal year). The quality measures include the five preventive care bonuses (pap smears, mammograms, flu shots, immunizations, and colorectal cancer screening). In our empirical analysis, all quantity measures are used in the logarithmic form while the preventive care bonuses are used as 0-1 indicators for whether the physician received the bonus.

The preventive care bonuses were briefly discussed in the previous section. Further details are described in Appendix Table 2. With the exception of colorectal screening that was introduced in 2006, all bonuses were available to both FHG and FHO physicians since 2007. For this reason, the sample period used for estimating the impact on preventive care bonuses is fiscal 2007 through 2009. Each bonus category specifies a target patient population (e.g. enrolled patients older than 65 years for the bonus for flu shots) as well as the minimum percentage of this population who received the targeted service that qualifies physicians for the bonus payment (e.g. 60 percent). The bonuses have several payment levels, ranging from $\mathrm{C} \$ 220$ to $\mathrm{C} \$ 2,200$, depending on the percentage of patients who received the targeted service ${ }^{23}$.

\footnotetext{
${ }^{21}$ We exclude observations in which the physician was not exclusively in either the FHO or FHG group. Our main results are not affected by this choice, as we document in the next section.

${ }^{22}$ The total number of physicians in 2009 is smaller than in 2006 because 301 physicians switched to a model other than the FHO or ceased to practice during the sample period.

${ }^{23}$ In 2008, two additional payment levels $(C \$ 3,300$ and $\mathrm{C} \$ 4,000)$ were introduced for the colorectal cancer screening.
} 
We excluded other performance-based incentives from our analysis because they applied to the FHO physicians only (the special payments), or were introduced towards the end of the sample period (the incentives to attach complex and vulnerable patients and unattached mothers with newborns were introduced in 2009, while the chronic disease management fee for congestive heart failure was introduced in 2008), or because they were significantly restructured during the sample period (the special payments). The analysis of the impact of the mixed capitation model on these incentives remains an area for future research.

The summary statistics for the sample physicians, as of 2006 when the FHO model was not yet introduced, are presented in the first two columns of Table 2. In this table, the treatment physicians are defined as physicians who eventually switched to the FHO model, while the control physicians are defined as physicians who remained in the FHG model throughout the sample period.

These statistics show some significant differences between the treatment and control physicians. In particular, the treatment physicians provide a significantly smaller number of services and visits per day, but they work significantly more days per year and have a significantly larger roster size than the control physicians. In addition, the treatment physicians are significantly more likely to be eligible for all preventive care bonuses ${ }^{24}$.

In terms of covariates, the treatment physicians are significantly younger and less likely to live in the Toronto Central Region than the control physicians, but there is no significant difference in gender composition between the two groups. Perhaps most significantly, there is a large and significant difference in the expected change in income from joining the FHO model: a

\footnotetext{
${ }^{24}$ The eligibility for preventive care bonuses is based on the actual payment in 2007 since four out of five bonuses were not introduced until then.
} 
gain of about $\mathrm{C} \$ 55,000$ for the treatment physicians and a loss of about - $\mathrm{C} \$ 11,000$ for the control physicians ${ }^{25}$.

These descriptive results clearly show that physicians who joined the FHO model were a selected, non-random group of FHG physicians. To partially address this selection problem, we use the propensity score matching to select a sub-sample of control physicians with observed covariates and outcomes most similar to the treatment physicians ${ }^{26}$. Specifically, we first estimate the probability of joining the FHO model (the propensity score) using all available covariates and outcomes as of $2006^{27}$. In the second step, we use the nearest neighbor matching to select which control physicians to include in the final sample, where each treatment physician is matched on the propensity score to the nearest control physician. We also use the replacement option which allows a control physician to be matched to more than one treatment physician.

The summary statistics for the matched control group are shown in the third column of Table 2. This sample consists of 843 physicians compared to 2,947 physicians in the full control sample. The matched control physicians are quite similar to the treatment physicians with respect to all pre-treatment covariates and outcomes. Moreover, none of the differences observed in the full sample are statistically significant.

\subsection{Empirical Strategy}

While the matching approach improves comparability between treatment and control physicians, its main shortcoming is that the two groups are matched on observable factors only. The concern

\footnotetext{
${ }^{25}$ The expected income in the FHO model was calculated using the actual billing profile to the enrolled and nonenrolled patients in fiscal 2006. We then used the definition of core services, comprehensive care services, and after-hour services to calculate the FFS part of the income and the patients' age and sex to calculate the net capitation rate. The access bonus was then calculated using the information on where the enrolled patients received core services, assuming that physicians in the same FHG group would continue practicing in the same group after they switch to the FHO model. Further details are available upon request.

${ }^{26}$ For theoretical reviews of the propensity score methods, see for example Rosenbaum and Rubin $(1983,1985)$ and Dehejia and Wahba (2002). For implementation in STATA, see Leuven and Sianesi (2003).

${ }^{27}$ The full set of results is available upon request.
} 
is that physicians may also differ with respect to unobservable factors that influence both the physician choice of which model to join and the outcomes of interest. In addition, the two groups of physicians may experience differential trends in outcomes for reasons other than joining the FHO model.

To address this concern, we exploit the longitudinal nature of our data to control for unobserved differences between physicians that are time invariant and for physician-specific trends in outcomes. Specifically, we estimate the following model:

$$
y_{\mathrm{it}}=\gamma_{\mathrm{i}}+\lambda_{\mathrm{t}}+\theta_{\mathrm{i}} t+w_{\mathrm{it}}^{\prime} \beta+\delta F H O_{\mathrm{it}}+u_{\mathrm{it}}
$$

where $y_{\mathrm{it}}$ represents the outcome of interest for physician $i$ in year $t ; \gamma_{\mathrm{i}}$ is the set of physician fixed effects; $\lambda_{\mathrm{t}}$ is the set of year fixed effects; $\theta_{\mathrm{i}}$ is the trend for physician $i ; w_{\mathrm{it}}$ is the set of timevarying physician characteristics; and $F H O_{\text {it }}$ is the treatment indicator equal to 1 if the physician is in the FHO model at time $t$ and 0 if the physician is in the FHG model.

This model is sometimes called the correlated random trend model and resembles the standard difference-in-difference model, except that the differences are calculated for the same physicians over time rather than the same groups ${ }^{28}$. In this model, the coefficient $\delta$ represents the difference in outcomes between treatment and control physicians, controlling for fixed physician and year effects and physician-specific linear trends. This coefficient identifies the causal impact of joining the $\mathrm{FHO}$ provided that changes in treatment $\left(\triangle F H O_{\mathrm{it}}\right)$ in any time period are not correlated with idiosyncratic changes in outcomes $\left(\Delta u_{\mathrm{it}}\right)$. This seems to be a reasonable assumption in our sample because physicians who joined the FHO model never reverted back to the FHG model.

\footnotetext{
${ }^{28}$ See for example Imbens and Wooldridge (2007).
} 
We estimate the model by first differencing equation (3) to remove individual fixed effects and then applying a fixed effects estimator, using weights from the matching step to account for the fact that some control physicians are matched to more than one treatment physician and using the robust Huber-White standard errors clustered at the physician level to account for clustering and serial correlation. We also bootstrap the estimate of $\delta$ and its standard error using 500 replications to account for the estimation error in the propensity score and the variation that it induces in the matching process.

\section{Impact on Quantity and Quality Outcomes}

\subsection{Main Results}

Our main results are presented in Table 3. For comparison purposes, we present results from the least squares model, the fixed effects model, and the correlated random trend model. These models use progressively less restrictive identification assumptions about the fixed effects and trends in outcomes. In addition, we present the results using both full and matched samples to assess the robustness of our results with respect to the choice of control group.

The results from our preferred correlated random trend model with the matched sample of control physicians are presented in the first column. These results suggest that joining the FHO model has a significant negative impact on the number of services and visits per day and a significant positive impact on the preventive care bonuses for flu shots, pap smears, mammograms, and immunizations. The reduction in services and visits is about 6 and 7 percent per day, respectively, or about 2 services and visits per day, while the increase in the probability of qualifying for one of the four bonuses ranges between 8 and 15 percent. On the other hand, 
the results indicate no significant impact on the annual days of work, the roster size, and the bonus for colorectal screening.

The results from the fixed effects and least squares models are presented in the second and third column, respectively. These results confirm a negative significant impact on services and visits and a positive significant impact on bonuses for flu shots, pap smears, mammograms, and immunizations. However, the estimates from the least squares model for services and visits are more than twice as large as those from the other two models, suggesting the importance of controlling for unobserved physician heterogeneity. In addition, the significance of the FHO impact on the roster size and the bonus for colorectal screening is significant only in the fixed effects model.

We further explore the robustness of these results by using the full sample of control physicians. These results, presented in the last three columns, indicate that the choice of control group does not qualitatively change our conclusions regarding the impact on services, visits, and bonuses for flu shots and pap smears. However, the choice of control group affects the significance of FHO impact for the annual days, the roster size, and the bonuses for colorectal screening, mammograms, and immunizations.

In summary, then, our preferred results indicate a negative FHO impact on services and days and a positive impact on most preventive care bonuses. With few noted exceptions, these results are quite robust to alternative identification assumptions and the choice of control group.

\subsection{Specification Checks}

The estimates in Table 3 are based on samples selected using the nearest neighbor matching, where each treatment physician is matched to the single nearest control physicians. An 
alternative sample selection method is the caliper matching, where the control physicians are included only if their propensity score lies within a specified distance from the treatment physicians. The choice between the two types of matching depends on the trade-off between bias and efficiency, with the caliper matching having generally smaller standard errors but potentially a larger bias ${ }^{29}$. As shown in the first column of Table 4, however, the choice between the two methods has a minimal impact on our main results, although the quantitative impact on the preventive care bonuses seems to be stronger using the caliper matching.

Our estimates in Table 3 are also based on a specific definition of the treatment indicator (the proportion of year during which the physician was affiliated with the FHO model rather than the FHG model). In the last two columns of Table 4, we examine the sensitivity of our results to two alternative definitions of treatment. The first alternative definition is to extend our treatment group to physicians in any mixed capitation model and not only the FHO model ${ }^{30}$. The second alternative definition uses only physicians who are in either FHO or FHG model for the entire year. This definition effectively transforms the continuous treatment indicator into a 0-1 indicator since it excludes years in which physicians were only partially in the FHO model (i.e. they either switched from the FHG to the FHO during the year or they ceased to practice).

Again, the results confirm our earlier findings of a negative and statistically significant impact on services and visits and a positive and statistically significant impact on the preventive care bonuses for flu shots, pap smears, and immunizations. The only exception is that the FHO impact on the bonus for mammograms is not significant when the treatment group includes physicians in any mixed capitation model.

\footnotetext{
${ }^{29}$ See for example Dehejia and Wahba (2002).

${ }^{30}$ The main other mixed capitation model is the Family Health Network (FHN) model that was introduced in Ontario in 2002, but never quite achieved the popularity of the FHO model. The main difference between the two models is in their basket of core services (less than 60 in the FHN and over 100 in the FHO).
} 


\subsection{Dynamics and General Equilibrium Effects}

In this section, we explore two complementary approaches to further test the causal interpretation of our results. The first approach is to examine the dynamics of the FHO impact. Specifically, if joining the FHO model has an impact on physician behaviour, then we should expect to observe this impact in years after the physician switches to the FHO model, but not in the prior years. The results from this analysis are shown in Table 5. The reported coefficients represent the FHO impact in a given year relative to two years prior to joining the FHO model. Therefore, these coefficients should be insignificant in the year prior to the switch and significant in the year after the switch, and possibly also in the year of switch.

These expectations are largely confirmed for services, visits, and preventive care bonuses for flu shots, pap smears, mammograms, and immunizations. While not conclusive, these results support the causal interpretation of the FHO impact. However, the impact on the roster size and the bonus for colorectal screening is significant even in the year prior to the switch, which suggests some anticipatory physician behaviour. Nevertheless, the impact after the switch is significantly larger than in any previous year, suggesting that the FHO model had an impact over and above the pre-existing trends.

Our second approach tests for the presence of general equilibrium effects. These would occur, for example, if the reduction in the volume of services and visits by the FHO physicians led to an offsetting increase by the FHG physicians. If this was the case, it would compromise the validity of using the FHG physicians as a control group.

To examine this hypothesis, we use the sample of FHG physicians only and study whether their outcomes depend on the number of mixed capitation physicians practicing in the same region. For robustness, we study this effect using both the FHO physicians only and using 
any mixed capitation physicians. In addition, we explore two measures of region of practice: the larger Local Health Integration Area (LHIN) as well as the more local sub-LHIN area. The results are presented in Table 6. Overall, the results provide little evidence to support the presence of general equilibrium effects. The only exception is the positive and significant impact on the roster size in a model that uses the number of FHO physicians, but even in this case, the sign of the impact is inconsistent with general equilibrium effects.

\subsection{Sub-Group Analysis}

The results reported in Table 3 represent the average impact of joining the FHO model. In this section, we examine how this impact varies for specific groups of treatment physicians.

In Table 7, we examine the FHO impact by age, sex, and rurality ${ }^{31}$. The results indicate that the negative impact on services and visits is stronger for younger physicians (under 50 years of age) compared to older physicians, but there are no significant differences between males and females and between rural and urban physicians. On the other hand, the positive impact on the preventive care bonuses seems to be stronger for female and younger physicians relative to male and older physicians, respectively.

In addition, we study the FHO impact by physician experience in a primary care model. Specifically, we divide the sample into two groups: those who were in the FHG model for at least 18 months as of April 2006 and those were in the FHG model less than 18 months ${ }^{32}$. The results are presented in the first two columns of Table 8 and indicate that the negative impact on services and visits is relatively larger for physicians who were in the FHG model longer than 18

\footnotetext{
${ }^{31}$ The rurality is measured using the Rurality Index of Ontario (see Kralj, 2000). This index is used by the Ontario Ministry of Health and Long-Term Care in many programs (e.g. Continuing Medical Education) that provide additional incentives to physicians living in rural or remote areas. The index ranges between 0 and 100 , with a threshold of $45+$ often used to identify rural and remote areas.

${ }^{32}$ The period of 18 months was chosen to obtain two groups of similar sample size.
} 
months and that the positive impact on preventive care bonuses is relatively stronger for physicians who were in the FHG model for less than 18 months.

Lastly, we also examine the FHO impact by income levels. The results are shown in the last three columns of Table 8 and indicate that the FHO impact is overall quite similar at all levels of income, with the exception that that the negative impact on the annual days of work tends to be significantly negative at higher income levels.

To summarize, these results suggest that the FHO impact varies across different physician groups. In particular, the negative impact on services and visits is more pronounced among younger physicians and physicians with a relatively shorter experience with primary care models. On the other hand, the positive impact on the preventive care bonuses is stronger among female physicians, younger physicians, and physicians with a relatively longer experience with primary care models.

\subsection{Discussion}

Our main results indicate that physicians in the FHO model provide about 6 and 7 percent fewer services and visits per day, respectively, than comparable physicians in the FHG model. These estimates are surprisingly close to the results reported by Dumont et al. (2008) who study the impact of a mixed payment system on the specialists in Quebec. However, these authors also find that the physicians increased their time per service and time spent on other activities such as teaching and administration. While we lack information on the actual time spent on various activities, the fact that we find no impact on the annual days of work is consistent with these results. 
In addition, our finding that the FHO model has no impact on the number of enrolled patients may at first seem puzzling. However, the result is less surprising if we recall that most financial incentives that the FHG physicians receive over and above the pure FFS model are for services provided to their enrolled patients only. These incentives include the 10 percent comprehensive care premium, the 20 percent after-hour premium, the Comprehensive Care Capitation fee, incentives to attach patients with no family doctor, and eligibility for preventive care bonuses and most special payments.

Lastly, our results indicate that physicians in the FHO model are between 8 and 15 percent more likely to qualify for the preventive care bonuses than physicians in the FHG model. However, these results do not imply that the preventive care bonuses have no impact on physicians in the FHG model. As Li et al. (2010) show, the primary care physicians in the enhanced FFS models provide more targeted preventive care services to their patients than physicians in the pure FFS model who are not eligible for these bonuses. Our contribution to this result is that we show that, even among physicians eligible for the preventive care bonuses, the type of compensation model matters.

\section{Impact on Patient Selection and Referrals}

The capitation model, in which physicians receive a fixed payment for each enrolled patient but no additional payment for services they provide, has usually been criticized on two grounds. First, physicians in the capitation model may try to attract patients with lower than expected treatment costs (the patient selection or 'cream-skimming' problem). This incentive may arise if physicians observe patient characteristics that affect the expected treatment costs but are not captured in the risk-adjustment capitation formula (e.g. Ellis, 1998). Second, the capitation 
physicians may excessively refer patients to other physicians because they receive no compensation for additional services they provide to their enrolled patients (e.g. Blomqvist and Léger, 2005). In this section, we examine whether these two concerns may also be relevant in the mixed capitation model.

We study the patient selection issue using the age and sex of enrolled patients. Specifically, at the beginning of each fiscal year we calculate for each physician the average roster complexity as $\sum v_{a s} m_{a s} / \sum v_{a s}$, where $v$ is the number of enrolled patients in age group $a$ and of sex $s$, and $m$ is the 38 age-sex specific multipliers used by the Ministry of Health and Long-Term Care to risk-adjust capitation payments in the FHO model. In this analysis, we restrict our sample to physicians who were in either the FHG model or the FHO model for the entire year because physicians may switch models at any time and because the number and type of their enrolled patients may change over time. Our results, presented in the first column of Table 9, indicate that there is no significant difference in the average roster complexity between physicians in the two models. We also reach the same conclusion when restricting the sample to various physician groups. Therefore, our results suggest that the mixed capitation model has no impact on the patient selection based on the age and sex of patients.

To examine the concern that physicians in the mixed capitation model may excessively refer patients, we obtained information on all clinical services for which the sample physicians were listed as referring physicians ${ }^{33}$. We then normalized the total number of referrals by the total number of enrolled patients and used the logarithm of this ratio as our outcome variable. The results are presented in the second column of Table 9. These results indicate that physicians in the FHO model refer significantly fewer patients than comparable physicians in the FHG

\footnotetext{
${ }^{33}$ This includes referrals to both focused-practice family physicians and specialists. The results are qualitatively similar if we restrict the referrals to specialists only.
} 
model. The average estimated impact is about 4 percent, but there are significant differences across physician groups. Specifically, the impact is not significant for older physicians, physicians in rural areas, and physicians who were in the FHG model for at least 18 months. Among physician groups for which the estimated reduction is significant, the impact ranges between 3 and 9 percent. However, the estimated impact is not positive for any group of physicians, suggesting that joining the FHO model does not have an unintended consequence on the referral rates.

\section{Conclusion}

Understanding how physicians respond to incentives in various compensation models has been of policy interest for long time. We contribute to this debate by comparing selected quality and quantity outcomes between primary care physicians in a mixed capitation model (the Family Health Organization) and an enhanced FFS model (the Family Health Group) in Ontario, Canada. Our results indicate that physicians in the mixed capitation model provide about 6 to 7 percent fewer services and visits per day (about 2 services or visits per day), but are between 8 and 15 percent more likely to achieve preventive care bonuses than physicians in the enhanced FFS model. These results are important because they suggest that the mixed capitation model may be welfare improving relative to the FFS model if, as the critics argue, physicians in the FFS model tend to over-provide quantity but under-provide quality of care. We also find that the FHO physicians have lower referral rates and enroll patients of similar complexity compared to the FHG physicians.

In addition, we find that the positive impact on the preventive care bonuses is stronger among female physicians, younger physicians, and physicians with a relatively longer experience with primary care models. These results suggest that the effectiveness of performance-based 
quality incentives may be improved by considering how the impact of a mixed capitation model varies across different physician groups.

There are two main limitations to our study. First, the estimated impact of a mixed capitation model is necessarily a short-term impact because the model was introduced in Ontario only about four years ago. Future research is needed to confirm whether this impact persists in the long-run. Second, our results are perhaps best interpreted as the impact of a mixed capitation model on physicians who are treated (i.e. those who found it beneficial to switch to this model). Therefore, our results may not necessarily generalize to the entire population of primary care physicians.

Future research can build on our analysis in at least two ways. First, we have studied the impact of a mixed capitation model on preventive care bonuses only. Future research can consider this impact on other performance-based quality incentives, such as chronic disease management and incentives to attach patients. Second, our analysis focuses on the transition of physicians from the FHG model to the FHO model. However, it is also important to consider other new models for primary care physicians, focusing on determinants of transition between these models and the impact of this transition on physician behavior. 


\section{References}

Allard, M., Léger, P.T., Rochaix, L. 2006. Provider behaviour under competition. HEC Montréal (unpublished manuscript).

Blomqvist, A., Léger, P.T. 2005. Information asymmetry, insurance, and the decision to hospitalize. Journal of Health Economics 22: 617-635.

Chalkley, M., Malcomson, J.M., 1998. Contracting for health services when patient demand does not reflect quality. Journal of Health Economics 17(1), 1-19.

Dehejia, R.H., Wahba, S. 2002. Propensity-score matching methods for nonexperimental causal studies. The Review of Economics and Statistics 84(1): 151-161.

Dumont, E., Fortin, B., Jacquement, N., Shearer B. 2008. Physicians' Multitasking and Incentives: Empirical Evidence from a Natural Experiment. Journal of Health Economics 27(6): 1436-1450.

Eggleston, K. 2005. Multitasking and mixed systems for provider payment. Journal of Health Economics 24, 211-223.

Ellis, R.P., 1998. Creaming, skimping and dumping: provider competition on the intensive and extensive margins. Journal of Health Economics 17: 537-555.

Evans, R.G. 1974. Supplier-induced demand: some empirical evidence and implications. In: The Economics of Health and Medical Care, Perlman, M. (Ed.), MacMillan, London, pp. 162-173.

Fortin, B., Jacquement, N., Shearer B. 2010. Labour Supply, Work Effort and Contract Choice: Theory and Evidence on Physicians. IZA Discussion Paper 5188.

Gruber, J., Owings, M. 1996. Physician Financial Incentives and Cesarean Section Delivery. Rand Journal of Economics, 27(1), 99-123.

Holmstrom, B., Milgrom, P., 1991. Multitask principal-agent analyses: incentive contracts, job design. Journal of Law, Economics and Organization 7 (special issue), 24-52.

Imbens, A., Wooldridge, J. 2007. What's new in econometrics? NBER Summer Institute, Chapter 10.

Kantarevic, J., Kralj, B., Weinkauf, D. 2011. Enhanced Fee-for-Service Model and Physician Productivity: Evidence from Family Health Groups in Ontario. Journal of Health Economics, 30(1): 99-111.

Kralj, B. 2000. Measuring 'rurality' for purposes of health-care planning: an empirical measure for Ontario. Ontario Medical Review. 
Léger, P.T. 2008. Physician Payment Mechanisms. In: Financing Health Care: New Ideas for a Changing Society, Lu, M. and Jonsson, E. (Eds.), Wiley, pp. 149-176.

Leuven E, Sianesi B. 2003. PSMATCH2: Stata module to perform full Mahalanobis and propensity score matching, common support graphing, and covariate imbalance testing. http://ideas.repec.org/c/boc/bocode/s432001.html. Version 3.1.5.

Li, J., Hurley, J., DeCicca, P., Buckley, G. 2011. Physician response to pay-for-performance evidence from a natural experiment. NBER Working Paper 16909.

Ma, C.A., McGuire, T.G., 1997. Optimal health insurance and provider payment. American Economic Review 87, 685-704.

McGuire, T.G., 2000. Physician agency. In: Culyer, A.J., Newhouse, J.P. (Eds.), Handbook of Health Economics, vol. 1A. North-Holland, Amsterdam, pp. 461-536.

McGuire, T.G. 2008. Physician Fees and Behavior: Implications for Structuring a Fee Schedule. In: Incentives and Choice in Health Care, Sloan, F. A., Kasper, H. (Eds.), M.I.T. Press.

Rosenbaum, P.R., Rubin, D.B. 1983. The central role of the propensity score in observational studies for causal effects. Biometrika 70(1): 41-55.

Rosenbaum, P.R., Rubin, D.B. 1985. Constructing a control group using multivariate matched sampling methods that incorporate the propensity score. The American Statistician 39(1): 33-38.

Rosser, W.W., Colwill, J.M., Kasperski, J., Wilson, L. 2010. Patient-centered medical homes in Ontario. New England Journal of Medicine 362(3): e7(1)-e7(3).

Smith PC, York N. 2004. Quality incentives: the case of U.K. general practitioners. Health Affairs 23(3): 112-118.

Yip, W. 1998. Physician response to Medicare fee reductions: changes in the volume of coronary artery bypass graft surgeries in the Medicare and private sectors. Journal of Health Economics 17, 675-699.

Zweifel, P., Breyer, F., Kiffman, M. 2009. Health Economics, $2^{\text {nd }}$ edition, Chapter 10. Paying providers, pp. 331-378. Springer-Verlag Berlin Heidelberg. 


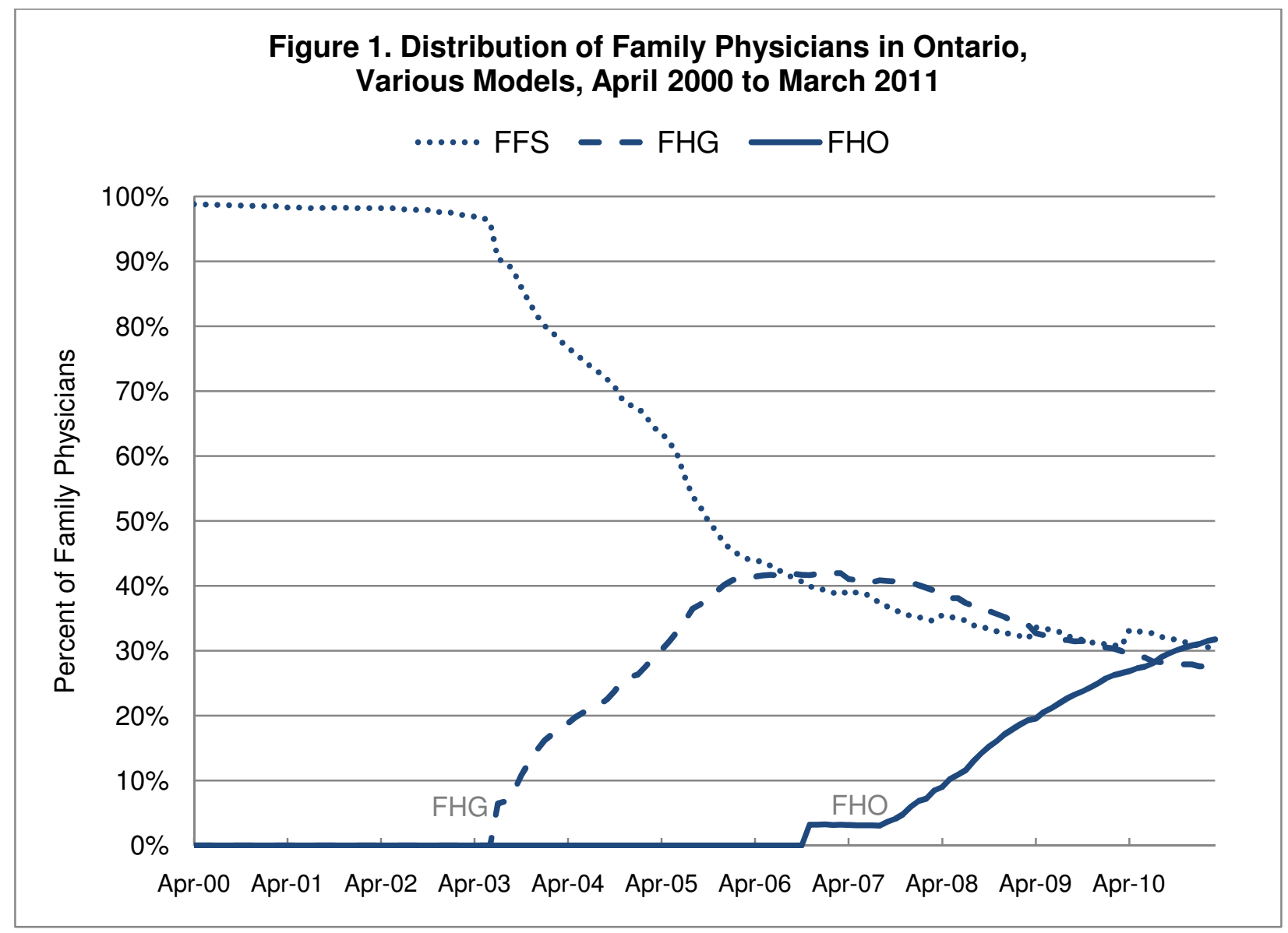

Source: Primary Health Care Status report, Ontario Ministry of Health and Long-Term Care. The number of physicians in the FHO model prior to its introduction in 2007 captures physicians in Health Service Organizations and Primary Care Networks who were 'grandfathered' into the FHO model. FFS $=$ fee-for-service, $\mathrm{FHG}=$ Family Health Groups, and FHO = Family Health Organizations. The FFS group includes physicians not affiliated with any patient enrolment model introduced during the primary care reform. The figure does not show physicians in other, smaller patient enrolment models (e.g. Family Health Network, Comprehensive Care Model). 


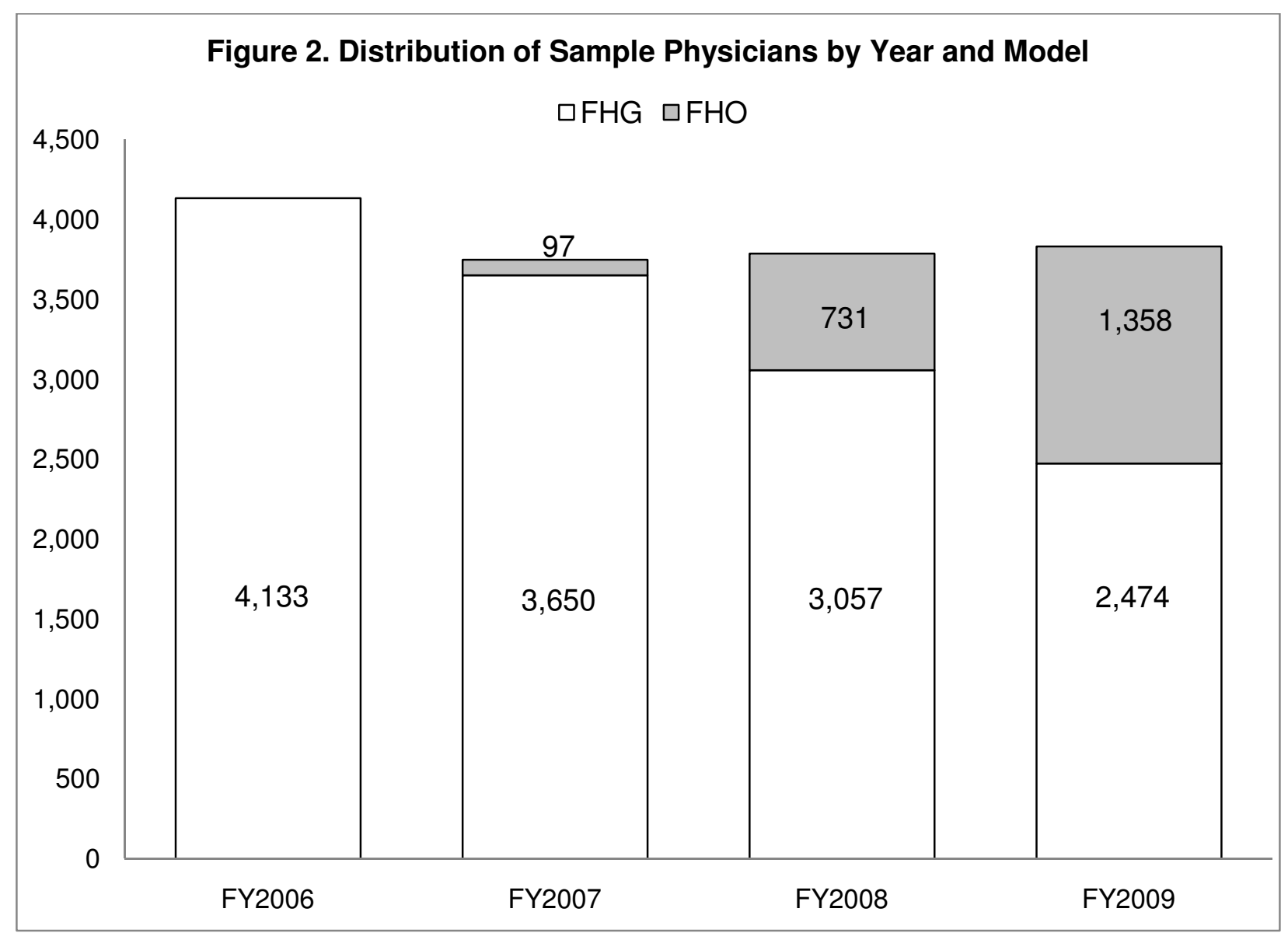


Table 1. Comparison of FHG and FHO models

\begin{tabular}{|c|c|c|}
\hline Elements & $\begin{array}{l}\text { Family Health } \\
\text { Group } \\
\text { (FHG) }\end{array}$ & $\begin{array}{c}\text { Family Health } \\
\text { Organization } \\
(\mathrm{FHO})\end{array}$ \\
\hline \multicolumn{3}{|l|}{ Organization } \\
\hline Group size & $\geq 3$ & $\geq 3$ \\
\hline Patient Enrolment ${ }^{1}$ & Yes & Yes \\
\hline After-Hours Requirement & Yes & Yes \\
\hline \multicolumn{3}{|l|}{ Base Compensation } \\
\hline Capitation Rate & No & Yes \\
\hline FFS Billings $^{2}$ & $100 \%$ & $10 \%$ \\
\hline CCC Fee & Yes & Yes \\
\hline \multicolumn{3}{|l|}{ Performance-based Incentives } \\
\hline Preventive Care Bonuses & Yes & Yes \\
\hline Chronic Disease Management & Yes & Yes \\
\hline Unattached Patients & Yes & Yes \\
\hline Special Payments $^{3}$ & No & Yes \\
\hline
\end{tabular}

NOTES.

$\mathrm{CCC}=$ Comprehensive Care Capitation .

${ }^{1}$ Mandatory in FHO, optional in FHG.

2 The FFS billings for FHG also include 10\% comprehensive care premium and $20 \%$ after-hours premium. The $10 \%$ shadow billings for $\mathrm{FHO}$ physicians apply only to core services provided to enrolled patients. The FHO physicians receive $100 \%$ on non-core services and core services provided to non-enrolled patients, up to a ceiling. The FHO physicians also receive the $20 \%$ after-hours premium, but no comprehensive care premium.

${ }^{3}$ The FHG physicians are eligible for palliative care and serious mental illness special payments. As of October 2009, all primary care physicians are eligible for special payments. 
Table 2. Summary Statistics, by Treatment Status, Fiscal Year 2006/07

\begin{tabular}{|c|c|c|c|}
\hline & \multirow{2}{*}{$\begin{array}{l}\text { Treatment } \\
\text { (FHO) }\end{array}$} & \multicolumn{2}{|c|}{ Control (FHG) } \\
\hline & & $\begin{array}{c}\text { Full } \\
\text { Sample }\end{array}$ & $\begin{array}{c}\text { Matched } \\
\text { Sample }\end{array}$ \\
\hline Number of Physicians & 1,530 & 2,947 & 843 \\
\hline \multicolumn{4}{|l|}{ Quantity Measures } \\
\hline Services per day & 39.3 & $43.4^{*}$ & 39.1 \\
\hline Visits per day & 27.8 & $29.5^{*}$ & 27.4 \\
\hline Annual workdays & 247 & $242^{*}$ & 249 \\
\hline Roster size (April 1, 2006) & 1,169 & $972^{*}$ & 1,201 \\
\hline \multicolumn{4}{|l|}{ Eligibility for Preventive Care Bonuses } \\
\hline Colorectal Screening & 0.45 & $0.32^{*}$ & 0.47 \\
\hline Flu shots for seniors & 0.45 & $0.32^{*}$ & 0.46 \\
\hline Pap smear & 0.49 & $0.35^{*}$ & 0.48 \\
\hline Mammogram & 0.51 & $0.34^{*}$ & 0.51 \\
\hline Toddler immunizations & 0.50 & $0.34^{*}$ & 0.52 \\
\hline \multicolumn{4}{|l|}{ Covariates } \\
\hline Average age & 48.5 & $50.5^{\star}$ & 48.9 \\
\hline Percent male & 0.62 & 0.65 & 0.64 \\
\hline Percent in Toronto Central Region & 0.11 & $0.13^{*}$ & 0.11 \\
\hline Expected Income gain (C\$) & 55,007 & $-11,389^{*}$ & 56,537 \\
\hline
\end{tabular}

NOTE. $F H O=$ Family Health Organization, $F H G=$ Family Health Group. ${ }^{*}$ indicates that the difference from the $\mathrm{FHO}$ group is significant at 0.05 level using the two-tail t-test. The t-tests are based on a regression of each variable on the treatment indicator. Before matching, this is an unweighted regression on the whole sample; after matching, the regression is weighted using the number of times each control physician is matched to a physician in the treatment group. 
Table 3. Impact of Joining FHO Model - Main Results

\begin{tabular}{|c|c|c|c|c|c|c|}
\hline \multirow[b]{2}{*}{ Dependent Variable } & \multicolumn{3}{|c|}{ Matched Control Sample } & \multicolumn{3}{|c|}{ Full Control Sample } \\
\hline & $\begin{array}{c}\text { Correlated } \\
\text { Trend }\end{array}$ & $\begin{array}{l}\text { Fixed } \\
\text { Effects }\end{array}$ & $\begin{array}{c}\text { Least } \\
\text { Squares }\end{array}$ & $\begin{array}{c}\text { Correlated } \\
\text { Trend }\end{array}$ & $\begin{array}{l}\text { Fixed } \\
\text { Effects }\end{array}$ & $\begin{array}{c}\text { Least } \\
\text { Squares }\end{array}$ \\
\hline \multicolumn{7}{|l|}{ Quantity Measures } \\
\hline Log of services per day & $\begin{array}{c}-0.0600^{\star * *} \\
(0.0099)\end{array}$ & $\begin{array}{c}-0.0521^{* * *} \\
(0.0098)\end{array}$ & $\begin{array}{c}-0.1550^{\star * *} \\
(0.0241)\end{array}$ & $\begin{array}{c}-0.0571^{* * *} \\
(0.0093)\end{array}$ & $\begin{array}{c}-0.0500^{* * *} \\
(0.0072)\end{array}$ & $\begin{array}{c}-0.1988^{\star * *} \\
(0.0156)\end{array}$ \\
\hline Log of visits per day & $\begin{array}{c}-0.0711^{* * *} \\
(0.0088)\end{array}$ & $\begin{array}{c}-0.0918^{* * *} \\
(0.0089)\end{array}$ & $\begin{array}{c}-0.1730 * * * \\
(0.0219)\end{array}$ & $\begin{array}{c}-0.0685^{\star * *} \\
(0.0082)\end{array}$ & $\begin{array}{c}-0.0902^{\star \star \star} \\
(0.0065)\end{array}$ & $\begin{array}{c}-0.2045^{\star \star *} \\
(0.0142)\end{array}$ \\
\hline Log of annual workdays & $\begin{array}{l}-0.0074 \\
(0.0206)\end{array}$ & $\begin{array}{c}0.0017 \\
(0.0124)\end{array}$ & $\begin{array}{l}-0.0258 \\
(0.0195)\end{array}$ & $\begin{array}{l}-0.0065 \\
(0.0197)\end{array}$ & $\begin{array}{c}0.0049 \\
(0.0078)\end{array}$ & $\begin{array}{c}0.0067 \\
(0.0130)\end{array}$ \\
\hline Log of roster size & $\begin{array}{c}0.0074 \\
(0.0231) \\
\end{array}$ & $\begin{array}{c}0.1129^{* * *} \\
(0.0251)\end{array}$ & $\begin{array}{c}0.0179 \\
(0.0440) \\
\end{array}$ & $\begin{array}{c}0.0061^{* * *} \\
(0.0240)\end{array}$ & $\begin{array}{l}-0.0272 \\
(0.0222)\end{array}$ & $\begin{array}{c}0.1759^{* * *} \\
(0.0319)\end{array}$ \\
\hline \multicolumn{7}{|l|}{ Preventive Care Bonuses } \\
\hline Colorectal Screening & $\begin{array}{c}0.0505 \\
(0.0331)\end{array}$ & $\begin{array}{c}0.0787^{* * *} \\
(0.0281)\end{array}$ & $\begin{array}{c}0.0344 \\
(0.0227)\end{array}$ & $\begin{array}{l}0.0512^{*} \\
(0.0291)\end{array}$ & $\begin{array}{c}0.0629^{* * *} \\
(0.0201)\end{array}$ & $\begin{array}{c}0.1300^{\star * *} \\
(0.0162)\end{array}$ \\
\hline Flu shots for seniors & $\begin{array}{c}0.1486^{\star * *} \\
(0.0364)\end{array}$ & $\begin{array}{c}0.1141^{\star * *} \\
(0.0270)\end{array}$ & $\begin{array}{c}0.0716^{\star \star *} \\
(0.0258)\end{array}$ & $\begin{array}{l}0.0717^{\star * *} \\
(0.0330)\end{array}$ & $\begin{array}{c}0.0855^{\star \star *} \\
(0.0206)\end{array}$ & $\begin{array}{c}0.1699^{\star * *} \\
(0.0172)\end{array}$ \\
\hline Pap smear & $\begin{array}{c}0.1250^{\star * *} \\
(0.0342)\end{array}$ & $\begin{array}{c}0.1061^{\star * *} \\
(0.0269)\end{array}$ & $\begin{array}{c}0.1079 * \star * \\
(0.0250)\end{array}$ & $\begin{array}{l}0.0541^{*} \\
(0.0307)\end{array}$ & $\begin{array}{c}0.0813^{* * *} \\
(0.0201)\end{array}$ & $\begin{array}{c}0.1960^{\star * *} \\
(0.0158)\end{array}$ \\
\hline Mammogram & $\begin{array}{l}0.0801^{* *} \\
(0.0333)\end{array}$ & $\begin{array}{c}0.0827^{* * *} \\
(0.0276)\end{array}$ & $\begin{array}{c}0.1026^{* * *} \\
(0.0238)\end{array}$ & $\begin{array}{l}-0.0040 \\
(0.0296)\end{array}$ & $\begin{array}{c}0.0531^{* * *} \\
(0.0199)\end{array}$ & $\begin{array}{c}0.1916^{* * *} \\
(0.0153)\end{array}$ \\
\hline Toddler immunizations & $\begin{array}{l}0.0891^{* *} \\
(0.0373)\end{array}$ & $\begin{array}{c}0.0871^{* * *} \\
(0.0278)\end{array}$ & $\begin{array}{l}0.0526^{\star *} \\
(0.0231)\end{array}$ & $\begin{array}{l}-0.0071 \\
(0.0037) \\
\end{array}$ & $\begin{array}{l}0.0432^{\star *} \\
(0.0207)\end{array}$ & $\begin{array}{c}0.1586^{\star \star \star} \\
(0.0162) \\
\end{array}$ \\
\hline Observations & 5,247 & 7,343 & 7,343 & 10,410 & 14,465 & 14,465 \\
\hline
\end{tabular}


Table 4. Specification Checks

\begin{tabular}{|c|c|c|c|}
\hline \multirow[b]{2}{*}{ Dependent Variable } & \multirow[b]{2}{*}{$\begin{array}{l}\text { Calliper } \\
\text { Matching }\end{array}$} & \multicolumn{2}{|c|}{ Treatment Indicator } \\
\hline & & $\begin{array}{c}\text { Any mixed } \\
\text { model }\end{array}$ & $\begin{array}{c}\text { Entire Year } \\
\text { Sample }\end{array}$ \\
\hline \multicolumn{4}{|l|}{ Quantity Measures } \\
\hline Log of services per day & $\begin{array}{c}-0.0547^{\star * *} \\
(0.0116)\end{array}$ & $\begin{array}{c}-0.0517^{* * *} \\
(0.0095)\end{array}$ & $\begin{array}{c}-0.0625^{\star \star *} \\
(0.0106)\end{array}$ \\
\hline Log of visits per day & $\begin{array}{c}-0.0699^{\star * *} \\
(0.0103)\end{array}$ & $\begin{array}{c}-0.0630^{* * *} \\
(0.0084)\end{array}$ & $\begin{array}{c}-0.0720^{\star * *} \\
(0.0095)\end{array}$ \\
\hline Log of annual workdays & $\begin{array}{l}-0.0067 \\
(0.0250)\end{array}$ & $\begin{array}{l}-0.0120 \\
(0.0183)\end{array}$ & $\begin{array}{l}-0.0089 \\
(0.0029)\end{array}$ \\
\hline Log of roster size & $\begin{array}{c}0.0131 \\
(0.0278)\end{array}$ & $\begin{array}{l}-0.0219 \\
(0.0246)\end{array}$ & $\begin{array}{c}0.0335 \\
(0.0253) \\
\end{array}$ \\
\hline \multicolumn{4}{|l|}{ Preventive Care Bonuses } \\
\hline Colorectal Screening & $\begin{array}{c}0.0583 \\
(0.0366)\end{array}$ & $\begin{array}{c}0.0042 \\
(0.0319)\end{array}$ & $\begin{array}{c}0.0568 \\
(0.0365)\end{array}$ \\
\hline Flu shots for seniors & $\begin{array}{c}0.1653^{* * *} \\
(0.0408)\end{array}$ & $\begin{array}{c}0.1138^{* * *} \\
(0.0348)\end{array}$ & $\begin{array}{c}0.1477^{* * *} \\
(0.0394)\end{array}$ \\
\hline Pap smear & $\begin{array}{c}0.1414^{* * *} \\
(0.0379)\end{array}$ & $\begin{array}{c}0.1028^{* * *} \\
(0.0328)\end{array}$ & $\begin{array}{c}0.1343^{* * *} \\
(0.0376)\end{array}$ \\
\hline Mammogram & $\begin{array}{c}0.1072^{* * *} \\
(0.0373)\end{array}$ & $\begin{array}{c}0.0516 \\
(0.0319)\end{array}$ & $\begin{array}{l}0.0838^{* *} \\
(0.0364)\end{array}$ \\
\hline Toddler immunizations & $\begin{array}{l}0.1063^{\star *} \\
(0.0414)\end{array}$ & $\begin{array}{l}0.0669^{\star} \\
(0.0362) \\
\end{array}$ & $\begin{array}{l}0.0997^{* *} \\
(0.0410)\end{array}$ \\
\hline Observations & 4,540 & 5,859 & 4,770 \\
\hline
\end{tabular}

NOTE. Each cell represents an estimate of $\delta$ for the dependent variable in the leftmost column. The estimates are obtained from the correlated random trend model with a matched sample of control physicians that also includes 4 year indicators and 14 regional indicators. Bootstrap standard errors in parentheses. *** indicates statistical significance at $1 \%$ level, ${ }^{* *}$ at $5 \%$ level, and ${ }^{*}$ at $10 \%$ level. The calliper matching uses the distance of 0.0005 . 
Table 5. Impact by Year of Switch

\begin{tabular}{|c|c|c|c|}
\hline Dependent Variable & $\begin{array}{c}\text { One Year } \\
\text { Before }\end{array}$ & $\begin{array}{c}\text { Year } \\
\text { of Switch }\end{array}$ & $\begin{array}{c}\text { One Year } \\
\text { After }\end{array}$ \\
\hline \multicolumn{4}{|l|}{ Quantity Measures } \\
\hline Log of services per day & $\begin{array}{c}0.0006 \\
(0.0060)\end{array}$ & $\begin{array}{l}-0.0166^{*} \\
(0.0095)\end{array}$ & $\begin{array}{c}-0.0515^{\star * *} \\
(0.0132)\end{array}$ \\
\hline Log of visits per day & $\begin{array}{l}-0.0037 \\
(0.0054)\end{array}$ & $\begin{array}{c}-0.0332^{* * *} \\
(0.0087)\end{array}$ & $\begin{array}{c}-0.0945^{\star * *} \\
(0.0118)\end{array}$ \\
\hline Log of annual workdays & $\begin{array}{l}-0.0056 \\
(0.0075)\end{array}$ & $\begin{array}{c}0.0117 \\
(0.0113)\end{array}$ & $\begin{array}{l}-0.0038 \\
(0.0153)\end{array}$ \\
\hline Log of roster size & $\begin{array}{c}0.0560^{\star \star \star} \\
(0.0212)\end{array}$ & $\begin{array}{c}0.1108^{\star * *} \\
(0.0301)\end{array}$ & $\begin{array}{c}0.1542^{* * *} \\
(0.0338)\end{array}$ \\
\hline \multicolumn{4}{|l|}{ Preventive Care Bonuses } \\
\hline Colorectal Screening & $\begin{array}{l}0.0492^{* *} \\
(0.0195)\end{array}$ & $\begin{array}{l}0.0588^{* *} \\
(0.0279)\end{array}$ & $\begin{array}{c}0.1328^{* * *} \\
(0.0331)\end{array}$ \\
\hline Flu shots for seniors & $\begin{array}{l}-0.0184 \\
(0.0189)\end{array}$ & $\begin{array}{c}0.0339 \\
(0.0261)\end{array}$ & $\begin{array}{c}0.0779 * * * \\
(0.0289)\end{array}$ \\
\hline Pap smear & $\begin{array}{l}-0.0052 \\
(0.0183)\end{array}$ & $\begin{array}{c}0.0216 \\
(0.0251)\end{array}$ & $\begin{array}{c}0.0923^{* * *} \\
(0.0280)\end{array}$ \\
\hline Mammogram & $\begin{array}{c}0.0186 \\
(0.0181)\end{array}$ & $\begin{array}{c}0.0402 \\
(0.0244)\end{array}$ & $\begin{array}{c}0.0994^{* * *} \\
(0.0268)\end{array}$ \\
\hline Toddler immunizations & $\begin{array}{c}0.0157 \\
(0.0177)\end{array}$ & $\begin{array}{l}0.0441^{*} \\
(0.0236)\end{array}$ & $\begin{array}{c}0.0771^{* * *} \\
(0.0260)\end{array}$ \\
\hline
\end{tabular}

NOTE. Each row represents an estimate of $\delta$ in the years indicated in the uppermost row relative to two years prior to joining the $\mathrm{FHO}$ model for the dependent variable in the leftmost column. The estimates are obtained from the correlated random trend model with a matched sample of control physicians that also includes 4 year indicators and 14 regional indicators. Bootstrap standard errors in parentheses. ${ }^{* * *}$ indicates statistical significance at $1 \%$ level, ${ }^{* *}$ at $5 \%$ level, and * at $10 \%$ level. 
Table 6. General Equilibrium Effects

\begin{tabular}{lccccc}
\hline \multirow{2}{*}{ Dependent Variable } & \multicolumn{2}{c}{ FHO Physicians } & & \multicolumn{2}{c}{ FHO and FHN Physicians } \\
\cline { 5 - 6 } Quantity Measures & Sub-LHIN & LHIN & & Sub-LHIN & LHIN \\
& & & & \\
Log of services per day & 0.0062 & -0.0041 & 0.0053 & 0.0070 \\
& $(0.0055)$ & $(0.0047)$ & $(0.0066)$ & $(0.0116)$ \\
Log of visits per day & 0.0034 & -0.0028 & 0.0026 & 0.0060 \\
& $(0.0046)$ & $(0.0041)$ & $(0.0064)$ & $(0.0105)$ \\
Log of annual workdays & 0.0002 & 0.0033 & 0.0119 & 0.0146 \\
& $(0.0064)$ & $(0.0051)$ & $(0.0080)$ & $(0.0114)$ \\
Log of roster size & $0.0509^{* *}$ & $0.0256^{\star *}$ & 0.0357 & 0.0391 \\
& $(0.0154)$ & $(0.0117)$ & $(0.0185)$ & $(0.0282)$ \\
\hline
\end{tabular}

Preventive Care Bonuses

Colorectal Screening

Flu shots for seniors

Pap smear

Mammogram

Toddler immunizations

\begin{tabular}{ccc}
0.0171 & -0.0173 & 0.0286 \\
$(0.0216)$ & $(0.0381)$ & $(0.0266)$ \\
0.0180 & -0.0178 & 0.0300 \\
$(0.0216)$ & $(0.0327)$ & $(0.0250)$ \\
0.00128 & -0.0178 & 0.0165 \\
$(0.0212)$ & $(0.0368)$ & $(0.0255)$ \\
0.0164 & -0.0222 & 0.0231 \\
$(0.0218)$ & $(0.0387)$ & $(0.0268)$ \\
0.0091 & 0.0102 & 0.0167 \\
$(0.0203)$ & $(0.0357)$ & $(0.0259)$ \\
\hline
\end{tabular}

0.0526

$(0.0714)$

0.0283

(0.0652)

0.0125

(0.0685)

0.0278

$(0.0725)$

0.0441

(0.0651)

\section{Observations}

3,406

4,823

4,670

5,257

NOTE. Each cell represents an estimate of the coefficient on the number of $\mathrm{FHO}$ (FHO and FHN physicians) for the dependent variable in the leftmost column. The estimates are obtained from the correlated random trend model that uses a sample of FHG physicians only. The model also includes 4 year indicators and 14 regional indicators. Bootstrap standard errors in parentheses. ${ }^{\star * *}$ indicates statistical significance at $1 \%$ level, ${ }^{*}$ at $5 \%$ level, and ${ }^{*}$ at $10 \%$ level. 
Table 7. Impact by Age, Sex, and Rurality

\begin{tabular}{|c|c|c|c|c|c|c|}
\hline Dependent Variable & $\begin{array}{l}\text { Age } \\
<50\end{array}$ & $\begin{array}{l}\text { Age } \\
\geq 50\end{array}$ & Female & Male & Rural & Urban \\
\hline \multicolumn{7}{|l|}{ Quantity Measures } \\
\hline Log of services per day & $\begin{array}{c}-0.0812^{\star * *} \\
(0.0144)\end{array}$ & $\begin{array}{c}-0.0382^{* * *} \\
(0.0143)\end{array}$ & $\begin{array}{c}-0.0617^{\star \star *} \\
(0.0171)\end{array}$ & $\begin{array}{c}-0.0591^{* \star *} \\
(0.0120)\end{array}$ & $\begin{array}{c}-0.0567^{* * *} \\
(0.0127)\end{array}$ & $\begin{array}{c}-0.0604^{\star \star \star} \\
(0.0163)\end{array}$ \\
\hline Log of visits per day & $\begin{array}{c}-0.0935^{\star \star *} \\
(0.0136)\end{array}$ & $\begin{array}{c}-0.0512^{\star \star *} \\
(0.0120)\end{array}$ & $\begin{array}{c}-0.0763^{\star * *} \\
(0.0166)\end{array}$ & $\begin{array}{c}-0.0677^{* * *} \\
(0.0100)\end{array}$ & $\begin{array}{c}-0.0714^{\star \star *} \\
(0.0108)\end{array}$ & $\begin{array}{c}-0.0688^{* * *} \\
(0.0160)\end{array}$ \\
\hline Log of annual workdays & $\begin{array}{c}-0.0450^{\star *} \\
(0.0205)\end{array}$ & $\begin{array}{c}0.0207 \\
(0.0359)\end{array}$ & $\begin{array}{l}-0.0437^{*} \\
(0.0252)\end{array}$ & $\begin{array}{c}0.0143 \\
(0.0290)\end{array}$ & $\begin{array}{c}0.0023 \\
(0.0297)\end{array}$ & $\begin{array}{c}-0.0256 \\
(0.0213)\end{array}$ \\
\hline Log of roster size & $\begin{array}{l}-0.0480 \\
(0.0401)\end{array}$ & $\begin{array}{c}0.0675^{\star \star *} \\
(0.0248)\end{array}$ & $\begin{array}{l}-0.0362 \\
(0.0407)\end{array}$ & $\begin{array}{c}0.0282 \\
(0.0280)\end{array}$ & $\begin{array}{c}0.0164 \\
(0.0269)\end{array}$ & $\begin{array}{l}-0.0340 \\
(0.0462)\end{array}$ \\
\hline
\end{tabular}

\section{Preventive Care Bonuses}

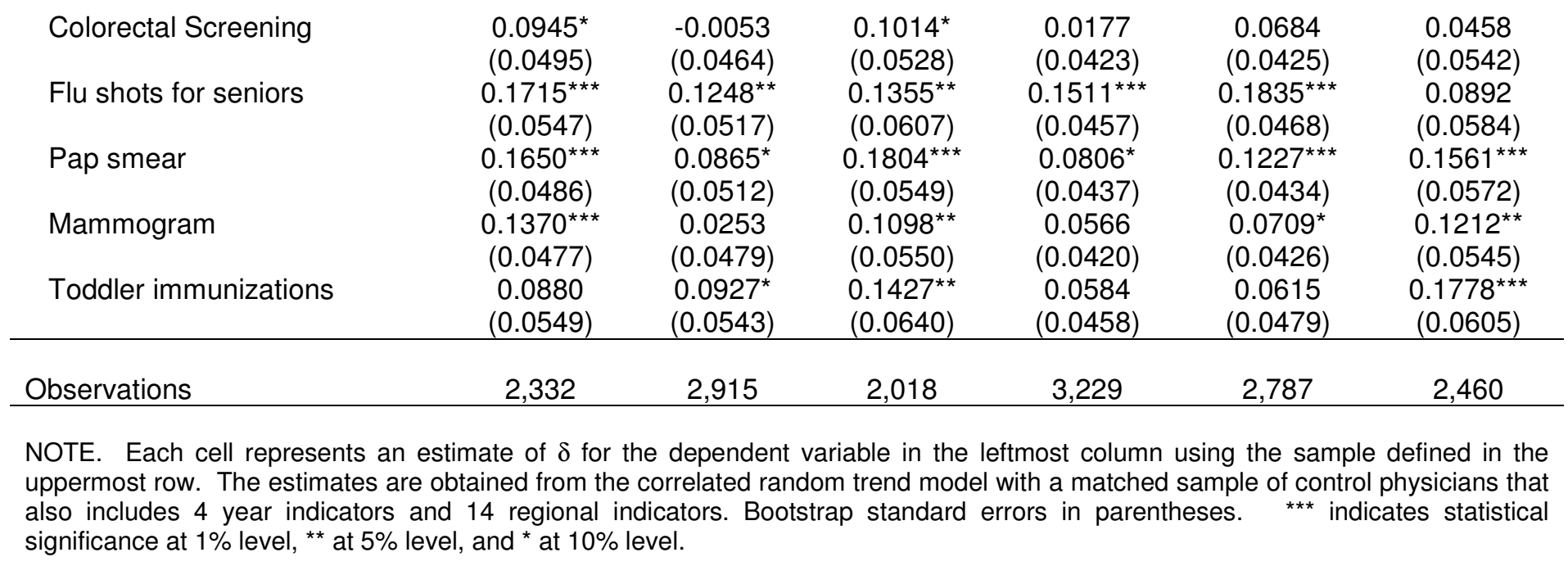


Table 8. Impact by Time in FHG and Income Levels

\begin{tabular}{|c|c|c|c|c|c|}
\hline Dependent Variable & $\begin{array}{c}\text { In FHG < } \\
18 \text { months }\end{array}$ & $\begin{array}{c}\text { In FHG } \geq 18 \\
\text { months }\end{array}$ & $\begin{array}{c}\text { Income } \\
>\$ 10 \mathrm{~K}\end{array}$ & $\begin{array}{c}\text { Income } \\
>\$ 50 \mathrm{~K}\end{array}$ & $\begin{array}{l}\text { Income } \\
>\$ 100 \mathrm{~K}\end{array}$ \\
\hline \multicolumn{6}{|l|}{ Quantity Measures } \\
\hline Log of services per day & $\begin{array}{c}-0.0297^{* *} \\
(0.0145)\end{array}$ & $\begin{array}{c}-0.0782^{* * *} \\
(0.0132)\end{array}$ & $\begin{array}{c}-0.0628^{* * *} \\
(0.0090)\end{array}$ & $\begin{array}{c}-0.0654^{* * *} \\
(0.0087)\end{array}$ & $\begin{array}{c}-0.0681^{* * *} \\
(0.0086)\end{array}$ \\
\hline Log of visits per day & $\begin{array}{c}-0.0479 * \star \star \\
(0.0140)\end{array}$ & $\begin{array}{c}-0.0853^{* * *} \\
(0.0113)\end{array}$ & $\begin{array}{c}-0.0733^{\star * *} \\
(0.0083)\end{array}$ & $\begin{array}{c}-0.0747^{* \star *} \\
(0.0081)\end{array}$ & $\begin{array}{c}-0.0778 * * * \\
(0.0079)\end{array}$ \\
\hline Log of annual workdays & $\begin{array}{l}-0.0245 \\
(0.0222)\end{array}$ & $\begin{array}{c}0.0032 \\
(0.0313)\end{array}$ & $\begin{array}{l}-0.0122 \\
(0.0163)\end{array}$ & $\begin{array}{c}-0.0255^{\star *} \\
(0.0105)\end{array}$ & $\begin{array}{c}-0.0288^{* * *} \\
(0.0098)\end{array}$ \\
\hline Log of roster size & $\begin{array}{l}-0.0248 \\
(0.0540) \\
\end{array}$ & $\begin{array}{l}0.0332^{* *} \\
(0.0161)\end{array}$ & $\begin{array}{c}0.0027 \\
(0.0229) \\
\end{array}$ & $\begin{array}{c}0.0027 \\
(0.0229) \\
\end{array}$ & $\begin{array}{l}-0.0009 \\
(0.0195) \\
\end{array}$ \\
\hline \multicolumn{6}{|l|}{ Preventive Care Bonuses } \\
\hline Colorectal Screening & $\begin{array}{l}0.0991 * \\
(0.0531)\end{array}$ & $\begin{array}{c}0.0261 \\
(0.0422)\end{array}$ & $\begin{array}{c}0.0502 \\
(0.0332)\end{array}$ & $\begin{array}{c}0.0507 \\
(0.0333)\end{array}$ & $\begin{array}{c}0.0459 \\
(0.0334)\end{array}$ \\
\hline Flu shots for seniors & $\begin{array}{c}0.1658^{* * *} \\
(0.0587)\end{array}$ & $\begin{array}{c}0.1374^{\star \star *} \\
(0.0467)\end{array}$ & $\begin{array}{c}0.1497^{\star \star *} \\
(0.0365)\end{array}$ & $\begin{array}{c}0.1505^{\star * \star} \\
(0.0367)\end{array}$ & $\begin{array}{c}0.1505^{\star \star *} \\
(0.0370)\end{array}$ \\
\hline Pap smear & $\begin{array}{c}0.1345^{\star *} \\
(0.0554)^{\star *}\end{array}$ & $\begin{array}{c}0.1227^{* * *} \\
(0.0436)\end{array}$ & $\begin{array}{c}0.1261^{* * *} \\
(0.0343)\end{array}$ & $\begin{array}{c}0.1269^{* * *} \\
(0.0344)\end{array}$ & $\begin{array}{c}0.1210^{* \star *} \\
(0.0348)\end{array}$ \\
\hline Mammogram & $\begin{array}{l}0.1317^{* *} \\
(0.0561)\end{array}$ & $\begin{array}{c}0.0474 \\
(0.0406)\end{array}$ & $\begin{array}{l}0.0811^{* \star} \\
(0.0334)\end{array}$ & $\begin{array}{l}0.0817^{* *} \\
(0.0335)\end{array}$ & $\begin{array}{l}0.0788^{* *} \\
(0.0337)\end{array}$ \\
\hline Toddler immunizations & $\begin{array}{l}0.1404^{\star *} \\
(0.0644) \\
\end{array}$ & $\begin{array}{c}0.0541 \\
(0.0452) \\
\end{array}$ & $\begin{array}{l}0.0901^{* *} \\
(0.0374)\end{array}$ & $\begin{array}{c}0.09004^{\star *} \\
(0.0375)\end{array}$ & $\begin{array}{l}0.0804^{* *} \\
(0.0379)\end{array}$ \\
\hline Observations & 2,385 & 2,862 & 5,241 & 5,190 & 5,080 \\
\hline
\end{tabular}

NOTE. Each cell represents an estimate of $\delta$ for the dependent variable in the leftmost column using the sample defined in the uppermost row. The estimates are obtained from the correlated random trend model with a matched sample of control physicians that also includes 4 year indicators and 14 regional indicators. Bootstrap standard errors in parentheses. ${ }^{* * *}$ indicates statistical significance at $1 \%$ level, ${ }^{* *}$ at $5 \%$ level, and ${ }^{*}$ at $10 \%$ level. 
Table 9. Impact on Patient Selection and Referrals

\begin{tabular}{lcc}
\hline Specification & $\begin{array}{c}\text { Log of } \\
\text { Age-Sex Modifier }\end{array}$ & $\begin{array}{c}\text { Log of } \\
\text { Referrals per Patient }\end{array}$ \\
\hline Base model & & \\
& 0.0274 & $-0.0389^{* * *}$ \\
Impact by sub-groups & $(0.1673)$ & $(0.0113)$ \\
Age $<50$ & & \\
& & \\
Age $\geq 50$ & -0.1476 & $-0.0608^{* * *}$ \\
Males & $(0.3159)$ & $(0.0193)$ \\
& 0.1185 & -0.0199 \\
Females & $(0.1604)$ & $(0.0134)$ \\
Rural & -0.0050 & $-0.0331^{* *}$ \\
& $(0.2198)$ & $(0.0133)$ \\
Urban & 0.0259 & $-0.0479^{* *}$ \\
& $(0.2526)$ & $(0.0205)$ \\
In FHG $<18$ months & -0.0124 & -0.0081 \\
In FHG $\geq 18$ months & $(0.1916)$ & $(0.0129)$ \\
& -0.0146 & $-0.0875^{* * *}$ \\
Income $>\$ 10 \mathrm{~K}$ & $(0.2984)$ & $(0.0230)$ \\
Income $>\$ 50 \mathrm{~K}$ & 0.0813 & $-0.0761^{* * *}$ \\
Income $>\$ 100 \mathrm{~K}$ & $(0.3106)$ & $(0.0207)$ \\
& -0.0332 & -0.0143 \\
& $(0.1787)$ & $(0.0134)$ \\
& -0.0149 & $-0.0404^{* *}$ \\
& $(0.1630)$ & $(0.0112)$ \\
& -0.0244 & $-0.0410^{* *}$ \\
& $(0.1632)$ & $(0.0112)$ \\
& -0.0409 & $-0.0413^{* * *}$ \\
& $(0.1654)$ & $(0.0110)$ \\
\hline
\end{tabular}

NOTE. The estimates are obtained from the correlated random trend model with a matched sample of control physicians that also includes 4 year indicators and 14 regional indicators. Bootstrap standard errors in parentheses. ${ }_{* * *}$ indicates statistical significance at $1 \%$ level, ${ }^{* *}$ at $5 \%$ level, and ${ }^{*}$ at $10 \%$ level. The sample for the log of age-sex modifier includes only physicians who were in the FHG or FHO model for the entire year. The estimates for the log of age-sex modifier model are multiplied by 100 to improve their readibility. 


\section{Appendix Table 1. Description of Data Sources}

\begin{tabular}{ll}
\hline Data Source & Variables Extracted for the Analysis \\
\hline 1. Ontario Health Insurance Plan & Physician clinical services, visits, and days \\
2. Corporate Provider Database & $\begin{array}{l}\text { Physician age, sex, and location } \\
\text { Physician type of primary care model }\end{array}$ \\
3. Architected Payment System & Preventive care bonus payments \\
4. Registered Persons Database & Patient age and sex \\
5. Client Agency Program Enrolment & Patient enrolment status \\
\end{tabular}

\section{Appendix Table 2. Preventive Care Bonuses}

\begin{tabular}{|c|c|c|c|}
\hline \multicolumn{2}{|c|}{ Bonus type } & \multirow{2}{*}{$\begin{array}{l}\text { Targeted Patients } \\
\text { Roster patients, age } 65 \text { or more, } \\
\text { who received the flu shot in the } \\
\text { previous flu season. }\end{array}$} & \multirow[b]{2}{*}{$\begin{array}{l}\text { Payment Levels } \\
\$ 220 \text { (60\% of patients) } \\
\$ 440 \text { (65\% of patients) } \\
\$ 770(70 \% \text { of patients) } \\
\$ 1,100(75 \% \text { of patients) } \\
\$ 2,200 \text { (80\% of patients) }\end{array}$} \\
\hline 1 & $\begin{array}{l}\text { Flu shots } \\
\text { - } \quad \text { Effective April 1, } 2007\end{array}$ & & \\
\hline 2 & $\begin{array}{l}\text { Pap smears } \\
-\quad \text { Effective April 1, } 2007\end{array}$ & $\begin{array}{l}\text { Rostered female patients, age } 35 \text { to } \\
69, \text { who received a pap smear for } \\
\text { cervical cancer during the last } 30 \\
\text { months. }\end{array}$ & $\begin{array}{l}\$ 220(60 \% \text { of patients }) \\
\$ 440(65 \% \text { of patients }) \\
\$ 660 \text { (70\% of patients) } \\
\$ 1,320(75 \% \text { of patients) } \\
\$ 2,200(80 \% \text { of patients) }\end{array}$ \\
\hline 3 & $\begin{array}{l}\text { Mammograms } \\
\text { - } \quad \text { Effective April 1, } 2007\end{array}$ & $\begin{array}{l}\text { Rostered female patients, age } 50 \text { to } \\
69 \text {, who received a mammogram for } \\
\text { breast cancer during the last } 30 \\
\text { months. }\end{array}$ & $\begin{array}{l}\$ 220(55 \% \text { of patients }) \\
\$ 440(60 \% \text { of patients }) \\
\$ 770(65 \% \text { of patients }) \\
\$ 1,320(70 \% \text { of patients }) \\
\$ 2,200(75 \% \text { of patients) } \\
\end{array}$ \\
\hline 4 & $\begin{array}{l}\text { Immunization } \\
\text { - } \quad \text { Effective April 1, } 2007\end{array}$ & $\begin{array}{l}\text { Rostered children, age } 30 \text { to } 42 \\
\text { months, who received } 5 \\
\text { immunizations by the age of } 30 \\
\text { months. }\end{array}$ & $\begin{array}{l}\$ 440 \text { (85\% of patients) } \\
\$ 1,100(90 \% \text { of patients) } \\
\$ 2,200(95 \% \text { of patients })\end{array}$ \\
\hline 5 & $\begin{array}{l}\text { Colorectal cancer screening* } \\
\text { - } \quad \text { Effective April 1, } 2006\end{array}$ & $\begin{array}{l}\text { Rostered patients, age } 50 \text { to } 74 \text {, } \\
\text { who were administered a colorectal } \\
\text { screening test by Fecal Occult } \\
\text { Blood Testing during the last } 30 \\
\text { months. }\end{array}$ & $\begin{array}{l}\$ 220(15 \% \text { of patients }) \\
\$ 440(20 \% \text { of patients }) \\
\$ 1,100(40 \% \text { of patients }) \\
\$ 2,200(50 \% \text { of patients) }\end{array}$ \\
\hline
\end{tabular}

\footnotetext{
* In 2008, two additional payments levels were introduced for colorectal cancer screening: $\$ 3,300$ for $60 \%$ of patients and $\$ 4,000$ for $70 \%$ of patients.
} 